\title{
RETURN TO ACTION
}

\author{
Jes Wienberg
}

So we gotta get off our arses and stop just talking about it! Hear! Hear! I agree! It's action that counts, not words, and we need action now! You're right. We could sit around here all day, talking, passing resolutions, make clever speeches, it's not gonna shift one Roman soldier! So let's just stop gabbing on about it! It's completely pointless and it's getting us nowhere. I agree! This is a complete waste of time! They've arrested Brian! What? They've dragged him off! They're gonna crucify him! Right! This calls for immediate discussion! (Monty Python, The Life of Brian, movie 1979).

If you are haunted by anniversaries, the best thing is to ignore them! However, anniversaries as a periodical strategy of remembrance, sometimes of nostalgic feelings and mourning, may create an opportunity for applying new perspectives on both the past and the present, thereby creating new knowledge.

We are more haunted, I believe, by all the inaugural or keynote speakers, keynote lectures and keynote articles, where well-established scholars, flattered by the request, seriously point towards the future, trying to predict trends and to draw the lines for future research by others. This is an overestimated academic genre. It is a genre concerning power over the discourse in the present and at least attempts to exercise this power in the future as well, most often in vain.

However, and first of all, why in a multivocal world should we let anyone have a certain keynote status? Do they have a certain authority to lean back on? Or, as I would prefer, do they have good convincing examples to show? Secondly, are predictions about the future of any relevance to the community of teaching and research? Why not just wait and see what happens or clear your own path through the jungle of perspectives, methods and examples - free of authorities? Looking back on 
past predictions, they can normally be evaluated as misleading, wrong or ridiculous. Predictions in the present are defeated by the butterfly effect, by the unpredictable actions and events in years to come. And fortunately, new generations form their own destiny.

In the beginning Bjørnar Olsen shows ironic distance and hesitation about the task given to him by Current Swedish Archaeology as a keynote writer on some anniversaries in theoretical archaeology, then he swallows the assignment with commitment. It becomes a text of great interest for its reflections on theoretical archaeology, mainly in Scandinavia, with a more or less conscious bias towards Tromsø and the author himself. However, as the text is declared to be "a personal excursion" my (re)action must unavoidably be to play with both the man and the ball.

The text mentions two revolutions: The past revolution of postprocessual archaeology, and the present or future revolution with a re-materialization of archaeology. And the text emphasizes four trends: a new geography, a turn to things themselves, a farewell to interpretation and archaeology as archaeology.

Revolution in an academic context is a rhetorical keyword evoking awe and greatness, probably borrowed from Thomas Kuhn's paradigmatic revolutions. Who does not want to be the leader or at least be part of a revolution, even when this concept is of doubtful relevance to subjects such as archaeology?

Olsen describes the coming of the revolution to Tromsø (and himself) and his later visit to its birthplace in Cambridge back in the I980s, in language that arouses associations with religious experiences. Meeting the revolution "face to face"! The tone is also unreflectively nostalgic. The discussions were bold and enthusiastic in the good old days. It was a period of new discoveries, opening of doors and new territories, according to Olsen. After this a decline followed, a less polemical climate, a trivialization and a watering down. However, he sees the coming of a new revolution. Let it be! What I find remarkable here is how he writes Troms $\varnothing$ and himself into both revolutions with plenty of references throughout the whole text. Two of his own works (Olsen I987; Johnsen \& Olsen I992) is even mentioned as possible candidates for an anniversary in line with other publications of theoretical archaeology in Scandinavia.

First of all, regardless of the excellent merits of Tromsø and Olsen, I find these self-references strikingly unashamed. Secondly, they are a clear example of the genre of keynotes as a base for attempts to exercise power over the discourse, in this case over both the history and the future of theoretical archaeology. The keynote, as in so many other cases, is used to inscribe scholars with their favourite ideas, which happen to 
be identical with the author and his or her ideas, into the history of archaeology. Look, we were part of the former revolution and we are still going strong since we also are part of the coming revolution! Thirdly, how about the credibility as revolutionaries at the barricades, when the new revolution in almost every respect is opposite to the old one?

Back to things! Right, it is happening in theoretical archaeology these years and maybe it will continue as a reaction to the former linguistic and symbolic turn. However, most archaeologists in the field, in the museums and also many at the universities, have been deep into things as things all the time. What I do not understand is why it should be necessary to apply the philosophy of Martin Heidegger, as Olsen proposes, as a strategy to get closer to things themselves. Is that not a theoretical detour just revealing the difficulties of leaving old habits of thinking?

The four trends presented are in my opinion reasonable observations of some of the trends today. Yes, there are as far as I know no real centres of archaeology, but a number of competitive or collaborating nodes in the web - splendid! There is a conjectural return to things, even though I am not convinced that things are able to act on their own without humans. The return has much in common with cultural history and cultural archaeology, e.g. what has been criticized and attacked since the introduction of processual archaeology. A farewell to what is called "ridiculously heavy interpretative burdens"? Well, there will always be overreactions in revolutions which make you either laugh or cry. Overreaction is probably what constitutes a revolution, but who is able to decide what is a reasonable interpretation? Even an elk or a boat has or gradually acquires multiple meanings, when cut into the rock. Instead I will reformulate the trend as a farewell to the heavy burdens of theorizing, not as a prediction, but as my aspiration. Finally, archaeology has always been inspired by other perspectives and other disciplines. But maybe a reification of archaeology or an introspection based on materiality might be a good thing as a way of exploring the potentials of the source material if new methods, borrowed from the natural sciences, are added.

I am sceptical, however, about to leave the ambitions of historic narrative, whether it is grand or small stories to be told, in order to become an alternative to history. Is the fragmented and incomplete character of the record, the "entangled mess we excavate", of interest to anyone but archaeologists? Could we imagine historians contemplating over the character of their perishable parchment and the dust of the archive instead of using it as a source? Occasionally maybe, but not always!

I am not waiting for an authority to open my eyes or guide me to a brave new world. I am not waiting for more words about revolutions, 
more gabbing or discussion. Let us have some action now, meaning good examples to be inspired or convinced by.

To confess, using a religious language, I am personally more curious about the (mostly) American trend of "action archaeology" putting the present-day questions of society into the core of archaeology. Archaeology with its long-time perspective and material knowledge tries here to contribute more directly to the big issues of today - a sustainable world, climate change, population growth, urbanization and peace. A publication from this new direction is by Jeremy A. Sabloff, "Archaeology Matters. Action Archaeology in the Modern World" (Sabloff 2008; also Little 2009; Stottman 2010). Allow me to mention a concrete example from this text of interest to me at least, namely the archaeological contributions to the present debate on "collapse" (Diamond 2005; cf. Sabloff 2008:33ff).

A consequence of promoting action archaeology would be to redirect theoretical debate on materiality to the backyard. Having the key questions of the present at the forefront of archaeological debate would probably mean that other perspectives, methods and sources are more relevant to explore.

Action archaeology could be called a re-politicization of archaeology, perhaps a return to a nostalgic I970s, but this time from other starting points. Action archaeology is in the opposite direction of having the excavation as a theatre of experience and having Indiana Jones as a role model in an archaeology defined as a part of popular culture (cf. Holtorf 2005). Action archaeology definitely would mean serious (re)entanglement with Interpretation, History and Society!

Finally, as a double paradox I will give the last words to a wise chap, Brian: "Don't let anyone tell you what to do!" (Monty Python, The Life of Brian, movie I979)

Jes Wienberg Department of Archaeology and Ancient History Lund University Box II7 22I oo Lund Sweden

\section{REFERENCES}

Diamond, J. 2005. Collapse. How Societies Choose to Fall or Succeed. New York: Viking Press. 
Holtorf, C. 2005. From Stonehenge to Las Vegas. Archaeology as Popular Culture. Walnut Creek: AltaMira Press.

Johnsen, H. \& Olsen, B. I992. Hermeneutics and Archaeology. On the Philosophy of Contextual Archaeology. American Antiquity 57(3). Pp. 4I9-436.

Little, B. J. 2009. What Can Archaeology Do for Justice, Peace, Community, and the Earth? Historical Archaeology 43:4. Pp. II5-I 29.

Olsen, B. 1987. Arkeologi, tekst, samfunn. Fragmenter til en post-prosessuell arkeologi. Stensilserie B, historie/arkeologi 24. Tromsø: University of Tromsø.

Sabloff, J. A. 2008. Archaeology Matters. Action Archaeology in the Modern World. Key Questions in Anthropology. Walnut Creek, CA: Left Coast Press.

Stottman, M. J. (Ed.). 20I0. Archaeologists as Activists. Can Archaeologists Change the World? Tuscaloosa: The University of Alabama Press. 